\title{
HUBUNGAN PENGETAHUAN DENGAN PERILAKU MASYARAKAT DALAM MEMBUANG SAMPAH DI SUNGAI SAGO PEKANBARU
}

\author{
Suryani $^{1^{*}}$, Kursiah Warti Ningsih ${ }^{2}$ \\ ${ }^{1,2}$ Program Studi Ilmu Kesehatan Masyarakat STIKes Payung Negeri Pekanbaru \\ *Koresponden E-mail: suryaniwibowo87@gmail.com
}

\begin{abstract}
Based on a report by the Directorate General of Pollution and Environmental Damage Control of the Ministry of Environment and Forestry (KLHK), in 2015 nearly 68 percent or the majority of the quality of cistern water in 33 provinces in Indonesia was in a heavily polluted status. The main source of river pollutants is domestic or household waste. Human behavior is the biggest cause of environmental damage. The purpose of this study is to link knowledge with people's behavior in disposing household waste in the Sago River. This type of research is quantitative research with a cross-sectional approach. The independent variable in this study is people's knowledge in disposing household waste. The population in this study were all housewives who lived in the area around the Sago river, as many as 974 people. The samples in this study were 284 people and the sampling technique was Stratified Random Sampling. The instruments used were questionnaires and observation sheets. Primary data obtained through questionnaires and observations while secondary data from Sukaramai Kelurahan Pekanbaru data. Data analysis used chi square test with $\alpha=0.05$. The results showed that there was a relationship between knowledge and the behavior of disposing garbage with a value $\alpha<0,05$. This research would be used for further research, namely to make the right program in handling garbage in the Sago River in Pekanbaru.
\end{abstract}

Keywords: Knowledge, Behavior, Trash, River

Infeksi Saluran Pernapasan Akut (ISPA) Sampah adalah suatu bahan yang terbuang atau dibuang dari sumber hasil aktifitas manusia maupun alam yang belum memiliki nilai ekonomis. Sumber sampah antara lain rumah tangga, pertanian, perkotaan, perusahaan,, rumah sakit, Pertambahan jumlah penduduk di perkotaan yang pesat berdampak tehadap peningkatan jumlah sampah yang dihasilkan (Slamet, 2002).

Berdasarkan laporan yang dikeluarkan oleh Direktorat Jenderal Pengendalian Pencemaran dan Kerusakan Lingkungan Kementrian Lingkungan Hidup dan Kehutanan (KLHK), di tahun 2015 hampir 68 persen atau mayoritas mutu air sungan di 33 provinsi di Indonesia dalam status tercemar berat. Sumber utama pencemar sungai adalah limbah domestik atau rumah tangga.(Nationalgeographic, 2017)

Kota Pekanbaru merupakan salah satu dari sepuluh kota terbesar di Indonesia, dengan luas wilayah $632,27 \mathrm{~km} 2$ memiliki jumlah penduduk sekitar 1,3 juta penduduk. Dengan jumlah tersebut, tak heran jika pola produksi dan konsumsi di Kota Pekanbaru ini juga tinggi. Fakta ini pula yang menyebabkan produksi sampah di Kota Pekanbaru terus mengalami kenaikan setiap tahunnya. Dinas Kebersihan dan Pertamanan Kota Pekanbaru, menyatakan Pekanbaru mampu menghasilkan sampah 500 ton/hari. Secara rata- rata, 2,6 kilogram sampah diproduksi tiap penduduknya setiap hari (Efendi, 2018).

Berbagai jenis sampah baik yang degradable atau nondegradable akan tercampur jadi satu dan menimbulkan berbagai masalah seperti pencemaran,baik pencemaran bau, tanah ataupun air. Jika sampah tersebut dibuang ke peraiaran atau ke bantaran sungai terjadilah apa yang dinamakan "Pulau Sampah" dan tak terelakkan bencana banjirpun datang di mana-mana. (Susilowati, 2007).

Berdasarkan survey pendahuluan yang dilakukan terhadap 20 responden pada 3 April 2017 di pemukiman dekat DAS Sungai Sago Kelurahan Sukaramai Kota Pekanbaru didapatkan hasil bahwa 80 persen responden enggan membuang sampah pada tempatnya dengan alasan sudah merupakan kebiasaan secara turun temurun, tidak tahu dampak dari akibat membuang sampah ke sungai dan tidak adanya system pengelolaan sampah di pemukiman DAS. Berdasarkan hasil uji analisi parameter fisik, kimia dan biologis air sungai Sago yang dilakukan bersamaan dengan survey pendahuluan, didaptakan hasil bahwa sungai Sago telah mengalami pencemaran.

Di sekitar sungai Sago terdapat daerah pemukiman penduduk yang padat, selain itu juga terdapat pasar yang merupakan pusat perdagangan di kota Pekanbaru sehingga produksi sampah yang begitu banyak, para pedagang tidak memperhatikan kebersihannya, selain itu beberapa diantara pemukiman tesebut kondisinya terlihat dari kondisi fisiknya, air sungai berwarna keruh, berbau, dan dipenuhi sampah, kondisi tersebut kemungkinan karena perilaku masyarakat di sekitar sungai Sago dalam membuang sampah rumah tangga masih belum benar. Adanya sedimen dari sampah bisa mempercepat pendangkalan dan memungkinkan tersumbatnya sungai, sehingga saluran drainase yang fungsi utamanya mencegah banjir tidak akan mampu lagi menjalankan fungsinya.

Tujuan penelitian ini adalah untuk Mengetahui hubungan pengetahuan dengan perilaku masyarakat dalam membuang sampah rumah tangga di sungai Sago. 


\section{BAHAN DAN METODE}

Jenis penelitian yang dilakukan adalah penelitian kuantiatif dengan desain analitik melalui pendekatan Cross SectionalI. Pada studi Cross Sectional dimanasubjek diobservasi sekali saja melalui pengukuran dan pengamatan pada variable saat yang bersamaan dengan tujuan untuk melihat variabel bebas (independent) dan variabel terikat (dependent) yang dilakukan pada saat pengolahan data.

Penelitian ini dilakukan di Kelurahan Sukaramai yaitu pemukiman yang berada di sekitar Sungai Sago Kota Pekanbaru. Penelitian ini akan di rencanakan selama kurang lebih 1 tahun (12 bulan) dan akan di mulai setelah ditandatanganinya kontrak penelitian.

Populasi pada penelitian ini adalah adalah seluruh ibu rumah tangga yang bertempat tinggal di daerah sekitar sungai Sago yaitu Kelurahan Sukaramai Pekanbaru yaitu sebanyak 974 orang.

Sampel merupakan sebagian dari populasi. Dalam hali ini peneliti menggunakan rumus untuk penarikan sampel.

$$
\begin{aligned}
& \mathrm{N}=\frac{}{1+\mathrm{N}(\mathrm{d})^{2}} \\
& \mathrm{n}=\frac{974}{1+974(0,05)^{2}} \\
& \mathrm{n}=\frac{974}{1+974(0,0025)} \\
& \mathrm{n}=283,55=284 \text { orang }
\end{aligned}
$$

Teknik penarikan sampel yang akan digunakan pada penelitian ini adalah Stratified Random Sampling.

Sumber data dalam penelitian ini adalah Data sekunder berupa data monografi dari kelurahan Sukaramai sekitar Sungai Sago mengenai mata pencaharian penduduk dan rata-rata penghasilan penduduk. Dan data Primer berupa data responden yang berisi pengetahuan responden tentang pembuangan sampah rumah tangga.

Dalam penelitian ini instrumen yang digunakan adalah Kuesioner, digunakan untuk mengetahui data tentang pengetahuan dan perilakunya dalam membuang sampah rumah tangga di Sungai.

Analisa data disesuaikan dengan variabel yang akan diuji. Adapun analisa yang digunakan adalah analisa univariat dan analisa bivariat.

\section{HASIL}

\section{Distribusi Pengetahuan dan Perilaku Responden Dalam Membuang Sampah}

\begin{tabular}{|c|c|c|c|}
\hline No & Variabel & Frekuensi & $\%$ \\
\hline \multicolumn{4}{|c|}{ Variabel Dependen } \\
\hline \multirow[t]{5}{*}{1} & Perilaku Membua & & \\
\hline & Sampah & & \\
\hline & Buruk & 168 & 59,2 \\
\hline & Baik & 116 & 40,8 \\
\hline & Jumlah & 284 & 100 \\
\hline \multirow{5}{*}{2} & \multirow{2}{*}{\multicolumn{2}{|c|}{ Variabel Independen }} & \\
\hline & Pengetahuan Res & & \\
\hline & Cukup & 146 & 51,4 \\
\hline & Baik & 148 & 48,6 \\
\hline & Jumlah & 284 & 100 \\
\hline
\end{tabular}

Distribusi pengetahuan dan perilaku responden dalam membuang sampah dapat dilihat pada tabel berikut :

Tabel 1. Distribusi Pengetahuan dan Perilaku Responden Dalam Membuang Sampah

Berdasarkan tabel 1 di dapatkan responden dengan perilaku membuangan sampah yang buruk sebanyak $168(59.2 \%)$, dan responden dengan pengetahuan cukup sebanyak $146(51.4 \%)$.

\section{Perilaku Membuang Sampah}

Dari hasil penelitian didapatkan bahwa responden dengan perilaku membuangan sampah yang buruk sebanyak $168(59,2 \%)$.

\section{Pengetahuan}

Dari hasil penelitian didapatkan bahwa responden dengan pengetahuan cukup sebanyak 146 $(51,4 \%)$. Dasi hasil tersebut diketahu bahwa masyarakat sekitar mayoritas berpengetahuan cukup tentang penggelolaan sampah. Pengetahuan merupakan hasil tahu dan ini terjadi setelah orang melakukan penginderaan terhadap suatu obyek tertentu. Pengetahuan merupakan domain yang sangat penting dalam membentuk tindakan seseorang (overt behavior) (Notoadmojo, 2003).

\section{Hubungan Pengetahuan dengan Perilaku Masyarakat Dalam Membuang Sampah di Sungai Sago Kota Pekanbaru \\ Hubungan pengetahun dengan perilaku} masyarakat dalam membuang sampah di Sungai Sago Kota Pekanbaru dapat dilihat pada table berikut : 
Tabel 2. Hubungan Pengetahuan dengan Perilaku Masyarakat Dalam Membuang Sampah di Sungai Sago Kota Pekanbaru

\begin{tabular}{|c|c|c|c|c|c|c|c|}
\hline \multirow[b]{3}{*}{$\begin{array}{c}\text { Variabe } \\
1\end{array}$} & \multicolumn{5}{|c|}{ Perilaku Membuang Sampah } & \multirow{3}{*}{$\begin{array}{c}P \\
\text { Valu } \\
e\end{array}$} & \multirow{3}{*}{$\begin{array}{c}\text { OR } \\
(95 \% \mathrm{CI})\end{array}$} \\
\hline & \multicolumn{2}{|c|}{ Buruk } & \multicolumn{2}{|c|}{ Baik } & \multirow{2}{*}{$\begin{array}{l}\text { Total } \\
\mathrm{n}(\%)\end{array}$} & & \\
\hline & $\mathrm{n}$ & $\%$ & $\mathrm{n}$ & $\%$ & & & \\
\hline \multicolumn{8}{|c|}{ Pengetahuan } \\
\hline \multicolumn{8}{|c|}{ Responden } \\
\hline Cuku & 95 & 65.1 & 51 & 34.9 & 146 & 0.04 & 1.659 \\
\hline $\mathrm{p}$ & & & & & $(100)$ & 9 & $(1.029-$ \\
\hline Baik & 73 & 52.9 & 65 & 47.1 & $\begin{array}{c}138 \\
(100)\end{array}$ & & $2.672)$ \\
\hline Total & 168 & 59.2 & $\begin{array}{l}11 \\
6\end{array}$ & 40.8 & $\begin{array}{l}284 \\
(100)\end{array}$ & & \\
\hline
\end{tabular}

Berdasarkan hasil analisis bivariat pada tabel 2 dapat di simpulkan bahwa: Responden dengan pengetahuan cukup mempunyai perilaku buruk dalam membuang sampah 1,6 kali di bandingkan responden dengan pengetahuan baik

Dari hasil penelitian dapat disimpulkan bahwa ada hubungan antara pengetahuan dengan perilaku membuang sampah. Responden dengan pengetahuan cukup mempunyai perilaku buruk dalam membuang sampah 1,6 kali di bandingkan responden dengan pengetahuan baik.

\section{PEMBAHASAN}

Penanganan sampah berhubungan dengan perilaku masyarakat yang memproduksi sampah. Menurut Pramono (2005) dalam Ashiqiqy (2009), menangani sampah mulai dari hulu akan membuat permasalahan sampah menjadi sederhana. Menyadarkan masyarakat sebagai produsen sampah untuk tidak memproduksi sampah dalam jumlah banyak dan juga tidak membuang secara sembarangan, akan dapat mengurangi permasalahan sampah.

Pengetahuan baik dan memiliki perilaku yang tidak baik dalam mengolah sampah disebabkan oleh faktor kurangnya informasi mengenai cara pengolahan sampah yang baik (Harun, 2017).

Menurut Azwar (2001) seseorang yang berpengetahuan baik tentang pengelolaan sampah diartikan sebagai pengetahuan yang terdiri dari pengertian sampah, jenis sampah, sumber sampah, faktor yang mempengaruhi produksi sampah, pengaruh sampah terhadap kesehatan, masyarakat dan lingkungan, syarat tempat sampah, kegiatan operasional pengelolaan sampah dan alat yang digunakan dalam pengelolaan sampah dan cara membuang sampah, maka mereka akan mempunyai perilaku baik pula.

Tingkat pengetahuan responden mempengaruhi perilaku membuang sampah di sungai. Responden yang tidak dapat menjawab pertanyaan peneliti dengan benar dikarenakan kurangnya pengetahuan responden tentang pembuangan dan pengelolaan sampah yang benar.

Informasi merupakan faktor yang dapat mempengaruhi pengetahuan seseorang. Semakin banyak seseorang memperoleh informasi tentang pengolahan sampah yang baik maka pengetahuannya akan semakin baik dan akan memiliki perilaku yang baik pula (Harun, 2017).

\section{SIMPULAN}

Hasil Penelitian dapat disimpulkan bahwa mayoritas masyarakat memiliki perilaku membuangan sampah yang buruk sebanyak 168 (59.2\%), dan masyarakat mayoritas memiliki pengetahuan cukup sebanyak 146 (51.4\%).

Penelitian juga menunjukkan adanya hubungan antara pengetahuan dengan perilaku membuang sampah. Responden dengan pengetahuan cukup mempunyai perilaku buruk dalam membuang sampah 1,6 kali di bandingkan responden dengan pengetahuan baik

\section{UCAPAN TERIMA KASIH}

Dalam penyusunan laporan penelitian ini, saya tidak lepas dari bantuan dan pengarahan dari berbagai pihak yang telah membantu dengan ikhlas. Untuk itu, pada kesempatan kali ini peneliti ingin mengucapkan terima kasih yang sebesar - besarnya kepada segenap keluarga besar STIKes Payung Negeri Pekanbaru yang memberikan support moril dan materil. Pihak Keluarahan Sukaramai dan masyarakat Sukaramai yang telah bersedia menyempatkan diri untuk menjadi responden peneliti. Rekan Tim dalam penelitian yang membantu terlaksana kegiatan penelitian ini. Ibunda dan ayahanda tercinta yang tiada henti memberikan do'a, kasih sayang, motivasi serta dukungan moril dan materil kepada peneliti untuk menyelesaikan penelitian ini dan kepada seluruh keluarga yang selalu mendo'akan dan memberi semangat.

\section{DAFTAR PUSTAKA}

Ashidiqy, M.R. (2009). Analisis Faktor-Faktor Yang Berhubungan Dengan Perilaku Masyarakat Dalam Membuang Sampah Rumah Tangga di Sungai Mranggen. Universitas Negeri Semarang

Azrul, A., (2002). Pengantar Ilmu Kesehatan Lingkungan. Mutiara. Jakarta

Effendi, B. (2018). Pengaruh Peranan Bank Sampah Dallang Collection Terhadap kesejahteraan Karyawan Perspektif Ekonomi Syari'ah. Jurnal A1-Hikmah, 15 (02), 42-62.

Harun, H. (2017). Gambaran Pengetahuan dan Perilaku Masyarakat Dalam Proses Pemilahan Sampah Rumah Tangga di Desa Hegarmanah. Jurnal Aplikasi Ipteks Untuk Masyarakat, 6 (2), 86-88.

Nationalgeographic Indonesia, (2016). Air sungai di Indonesia tercemar berat. http://nationalgeographic.co.id 9.4619 mei 2017 
Notoatmojo, S. (2003). Ilmu Kesehatan Masyarakat Prinsip - Prinsip Dasar. Rineka Cipta. Jakarta.

Slamet, J.S. (2002). Kesehatan Lingkungan. Gadjah Mada University Press. Yogyakarta.

Susilowati, E. (2007). Sampah Masalah dan Solusinya.http://mst.ft.ugm.ac.d/concent/vie w/66/i/lang.id 